\title{
MENGENAL BISNIS YANG TAK KENAL RUGI DALAM PERSPEKTIF ISLAM
}

\author{
Sukma Mehilda \\ Sekolah Tinggi Ilmu Ekonomi (STIE) Syariah Bengkalis, Riau, Indonesia \\ sukma.mehilda@gmail.com \\ https://doi.org/10.46367/iqtishaduna.v9i2.236 \\ Received: Aug 28, 2020 Revised: Oct 24, 2020 Accepted: Nov 14, 2020 Published: Dec 17, 2020
}

\begin{abstract}
This paper aims to discuss the concept of business in Islamic review. In Islamic teachings, Allah guarantees sustenance for his creatures. This belief in assurance is what encourages business people to keep trying even though they have failed repeatedly. This treasure is also believed to be a deposit from God which must be treated as a means to achieve the common good. In describing the relationship between man and God, it turns out that the Al-Quran uses many terms commonly used in the business world. The key to success in business is faith as a foundation in righteous deeds. The higher the success achieved, the greater the responsibility and benefits that are carried out.
\end{abstract}

Keywords: Business, Faith Value, Islamic Business.

\begin{abstract}
ABSTRAK
Tulisan ini bertujuan untuk membahas mengenai konsep bisnis dalam tinjauan Islam. Dalam ajaran Islam, Allah menjamin rezeki bagi makhluknya. Kepercayaan pada jaminan inilah yang mendorong para pebisnis untuk terus berusaha walaupun berkali-kali menemui kegagalan. Harta itu pun diyakini sebagai titipan Allah yang mesti diperlakukan sebagai sarana untuk mencapai tujuan kemaslahatan bersama. Dalam menguraikan hubungan manusia dengan Tuhan, ternyata Al-Quran banyak menggunakan istilah-istilah yang lazim dipakai dalam dunia bisnis. Kunci sukses dalam berbisnis adalah iman sebagai fondasi dalam beramal saleh. Semakin tinggi kesuksesan yang diraih, semakin besar pula tanggung jawab dan kebermanfaatan yang dilakukan.
\end{abstract}

Kata Kunci: Bisnis, Nilai Keimanan, Bisnis Islami.

\section{PENDAHULUAN}

Bisnis merupakan bagian yang tidak terpisahkan dari kehidupan manusia. Kegiatan memenuhi kebutuhan hidup adalah kewajiban bagi seluruh umat muslim dan harus selalu berada di jalan yang lurus. Oleh sebab itu tujuan utama dari bisnis adalah mencapai ridha Allah SWT melalui aktivitas duniawi. Kegiatan memenuhi kebutuhan hidup ini merupakan kecenderungan alamiah dalam diri manusia untuk hidup dalam kenyamanan secara material (Khuza'i 2005). 
Persoalan bisnis juga terus berkembang sejalan dengan perkembangan ilmu-ilmu kemakmuran indrawi, yang jumlahnya pun makin lama makin bertambah banyak. Oleh karenanya peningkatan kemampuan untuk lebih kompetitif dalam memutar roda bisnis mutlak diperlukan agar manusia bisa mempertahankan keberlangsungan usahanya dalam situasi kompetisi yang semakin ketat (Amalia 2013). Kuatnya persaingan membuat seleksi alamiah yang mengarah pada yang kuat dan bertahan. Keberhasilan akan digapai oleh pelaku bisnis dan perusahaan yang paling mampu menyesuaikan diri dengan persyaratan lingkungan saat ini, yaitu mereka yang sanggup memberikan apa yang siap dibeli masyarakat. Oleh karenanya, tidak jarang demi keuntungan, banyak yang nekad menggunakan cara-cara yang batil. Mencari, memelihara dan mempertahankan bisnis dengan berbekal ilmu bisnis buatan kapitalis dan sosialis yang lepas dari nilai tauhid yang haq mengakibatkan mereka jauh dari Allah, tidak mendapat berkah dan akhirnya mengantarkan mereka pada kehancuran (Aryadi 2018).

Dalam hal inilah etika mempunyai peranan yang sangat penting dalam menjalankan bisnis. Dengan selalu berlandaskan etika dalam mengelola bisnis, ada jaminan bahwa roda bisnis akan berjalan dengan baik dan tentunya keuntungan yang menjadi tujuan bisnis juga akan mudah dicapai, baik keuntungan finansial maupun keuntungan yang sifatnya non materi, yaitu nilai-nilai yang lahir akibat adanya bisnis yang beretika atau disebut dengan sharia marketing (Khuza'i 2005).

Sharia marketing adalah sebagai sebuah disiplin bisnis strategi yang mengarah pada proses penciptaan, penawarandan perubahan nilai dari seorang produsen atau perusahaan atau perorangan kepada orang lain, yang dalam keseluruhan prosesnya sesuai dengan akad dan prinsip-prinsip bisnis dalam Islam (Miftah 2015). Bisnis Islami pada hakikatnya selalu memegang asas keadilan dan keseimbangan. Selain itu juga telah dicontohkan aplikasi nilai-nilai Islam dalam mengelola bisnis oleh Nabi Muhammad SAW. agar berhasil baik di dunia maupun di akhirat. Nilai-nilai bisnis Islam telah menjadi tren dalam mengendalikan tujuan dan harapan ekonomi dalam jangka panjang. Dengan mengedepankan kejujuran, kepercayaan, keadilan, professional dan komunikasi yang baik, maka muncul spirit moral dalam bisnis sehingga melahirkan bisnis atau usaha yang diberkahi (Heriyansyah 2018). Berdasarkan hal tersebut maka tulisan ini bertujuan untuk membahas mengenai konsep bisnis dalam tinjauan Islam.

\section{TELAAH LITERATUR}

Semua manusia terlibat dalam kegiatan bisnis, melalui bisnis manusia dapat memperoleh penghasilan, memenuhi kebutuhan akan barang dan jasa. Dunia bisnis bersifat dinamis, selalu bergerak maju, banyak inisiatif, kreatif, dan memberikan tantangan dalam menghadapi masa depan dengan penuh rasa optimis. Mobilitasnya tinggi, mereka bergerak dari satu daerah ke daerah yang lain, sesuai dengan musim, sesuai dengan situasi dan waktu yang tepat di satu daerah dan daerah dimana orang membutuhkan barang. Kegiatan bisnis antara lain yaitu menyediakan barang pada waktu yang tepat, jumlah yang tepat, mutu yang tepat dan harga yang tepat (Ludin, Saleh, and Amruloh 2018).

Bisnis memperlihatkan dirinya sebagai aktivitas riil ekonomi yang secara sederhana dilakukan dengan cara jual beli atau pertukaran barang dan jasa. Bisnis 
juga dapat dikatakan sebagai sebuah kegiatan yang terorganisir karena didalam bisnis ada banyak kegiatan yang dilakukan. Kegiatan dimulai dengan input berupa mengelola barang lalu di proses setelah itu menghasilkan output berupa barang setengah jadi atau barang jadi (Susidin 2010). Bisnis juga dipahami dengan suatu kegiatan usaha individu (privat) yang terorganisasi atau melembaga, untuk menghasilkan atau menjual barang atau jasa guna mendapatkan keuntungan dalam memenuhi kebutuhan masyarakat (Setiyawan 2013).

Menurut Chwee (1990), bisnis sebagai suatu sistem yang memproduksi barang dan jasa untuk memuaskan kebutuhan masyarakat. Sedangkan menurut Hughes dan Kapoor $(2004,20)$ bisnis adalah kegiatan usaha individu yang terorganisir untuk memperoleh laba atau menjual barang dan jasa guna mendapat kenutungan dan memenuhi kebutuhan masyarakat (Rangkuti 2005). Menurut Umar (2005, 3), pendapat Glos (1976) bisnis adalah seluruh kegiatan yang diorganisasikan oleh orang-orang yang berkecimpung dalam bidang perniagaan dan industri yang menyediakan barang dan jasa untuk kebutuhan mempertahankan dan memperbaiki standar serta kualitas hidup mereka (Sagita and Herlina 2015).

Ebert (2007) mendefinisikan bahwa bisnis sebagai sebuah organisasi yang mengelola barang dan jasa untuk mendapatkan laba. Dari definisi tersebut terdapat dua pengertian tentang bisnis, pertama, dapat dikatakan bisnis jika yang dilakukan adalah mengusahakan barang dan jasa. Kedua, bisnis adalah suatu kegiatan yang dilakukan untuk memperoleh laba (Setiyawan 2013).

Bisnis dapat diartikan juga sebagai sejumlah total usaha yang meliputi pertanian, produksi, konstruksi, distribusi, transportasi, komunikasi, usaha jasa dan pemerintahan yang bergerak dalam bidang membuat dan memasarkan barang dan jasa konsumen (Holle 2019). Istilah bisnis ini pada umumnya ditekankan pada tiga hal yaitu yang pertama, usaha perseroan kecil-kecilan. Yang kedua, usaha perusahaan besar seperti pabrik, transportasi, surat kabar, hotel dan sebagainya. Yang ketiga, usaha dalam bidang struktur ekonomi suatu negara. Dari definisi tersebut, dapat dikatakan bahwa bisnis merupakan serangkaian kegiatan yang terdiri dari tukar menukar, jual-beli, memproduksi-memasarkan, bekerjamempekerjakan dan interaksi manusia lainnya dengan maksud memperoleh keuntungan (Aldy, Riawan, and Sugianto 2017). Suatu organisasi atau pelaku bisnis akan melakukan aktivitas bisnis dalam bentuk: pertama, memproduksi dan atau mendistribusikan barang dan atau jasa. Kedua, mecari profit, dan yang ketiga mencoba memuaskan keinginan konsumen (Djakfar 2008).

Barang dapat diartikan dengan suatu produk yang berwujud secara fisik yang ianya dapat dilihat, serta disentuh secara nyata. Adapun jasa merupakan aktivitas-aktivitas (termasuk gagasan) yang dinilai dapat memberi manfaat bagi konsumen atau bisnis lainnya. Barang dan jasa ini dihasilkan dari sejumlah input yang diperlukan. Secara umum terdapat empat jenis input yang digunakan oleh seluruh pelaku bisnis, yaitu: (a) Sumber daya manusia, yang sekaligus berperan sebagai operator dan pengendalian organisasi bisnis. (b) Sumber daya alam, termasuk tanah dengan segala yang dihasilkannya. (c) Modal, meliputi keseluruhan alat dan perlengkapan, mesin serta bangunan, dan tentu saja dana yang dipakai dalam memproduksi dan mendistribukan barang dan jasa. (d) Entrepreneurship, yang terutama mencakup aspek ketrampilan dan keberanian untuk mengombinasikan ketiga faktor produksi diatas untuk mewujudkan suatu bisnis dalam rangka mengasilkan barang dan jasa. 
Setiap organisasi bisnis, baik yang memproduksi barang atau jasa, akan melakukan fungsi dan aktivitas yang sama. Setidaknya terdapat enam pokok aktivitas yang di garap oleh sebuah entenitas bisnis, yaitu: (a) Menciptakan atau memproduk suatu barang atau jasa. (b) Memasarkan produk kepada konsumen. (c) Membuat dan mempertanggung jawabkan transaksi keuangan. (d) Merekrut,mempekerjakan, melatih dan mengevaluasi karyawan. (e) Memperoleh dan mengelola dana. (f) Memproses informasi.

\section{PEMBAHASAN}

\section{Manusia Sebagai Khalifah}

Manusia bahkan makluk hidup dianugrahi oleh Allah naluri yang menjadikannya gemar memperoleh manfaat dan menghindari mudharrat, serta membenci lawan kedua hal itu. tidak ada perbedaan manusia menyangkut hal ini sejak kehidupan dikenal oleh makhluk (Arifin 2008). Seimbang dengan kelebihan atau kekurangan, demikian juga kesenangan dan kebencian. Untuk meraih apa yang disenanginya itu, atau menampik apa yang tidak disukainya, lahirlah dorongan fitrah yang mengantar kepada aneka aktivitas manusia. Allah berfirman dalam Al-Quran:

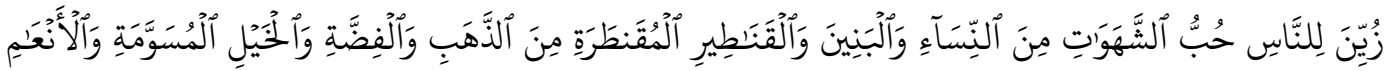

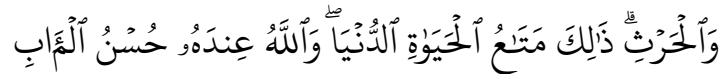

Artinya: "Dijadikannya indah pada (pandangan) manusia kecintaan kepada apaapa yang diingini, yaitu wanita-wanita, anak-anak lelaki, harta yang banyak dari jenis emas, perak, kuda pilihan, binatang-binatang ternak dan sawah lading. Itulah kesenangan hidup didunia dan di sisi Allah-lh tempat kembali yang baik (syurga)" (QS. Ali-'Imran 3:14).

Allah menjadikan hal-hal diatas indah bagi manusia secara naluriah atau fithriah karena Allah menugaskan makhluk sempurna ini membangun dan memakmurkan bumi (Holle 2019). Untuk melaksanakan tugas kekhalifahan itu, manusia harus memiliki naluri mempertahankan hidup ditengah aneka makhluk, baik dari jenisnya maupun dari jenis makhluk hidup yang lain, yang memiliki naluri yang sama. Naluri inilah yang merupakan pendorong utama bagi segala aktivitas manusia. Dorongan ini mencangkup dua hal pokok, yaitu memelihara diri dan memelihara jenis. Dari keduanya lahir aneka dorongan, seperti memenuhi kebutuhan sandang, pangan, papan, keinginan untuk memiliki, dan hasrat untuk menonjol. Semuanya berhubungan erat dengan dorongan/fitrah memelihara diri, sedang dorongan seksual berkaitan dengan upaya manusia memelihara jenisnya. Itulah sebagian fitrah yang dihiaskan Allah kepada manusia.

Di samping fitrah itu Allah menyiapkan juga sarana-sarana yang dapat digunakan makhluk yang bermukim di persada bumi ini untuk memenuhi kesukaannya itu. Khusus buat manusia, di samping yang disebut di atas, Allah menganugerahinya juga nafsu dan akal pikiran, menganugrahinya petunjuk agama agar memelihara mereka dari keterjerumusan mengikuti hawa nafsu.

Allah menyiapkan buat manusia dua sarana perolehan manfaat yaitu: materi yang disediakan-Nya untuk dimiliki dan tenaga dan pikiran yang harus diupayakannya. Materi yang dimaksud adalah kepemilikan sesuatu yang tumbuh dengan sendirinya, yaitu pepohonan yang tumbuh dan binatang yang berkembang 
biak, sedangkan tenaga dan pikiran adalah kegiatan yang mengantar kepada kepemilikan materi atau rekayasa yang menghasilkan pemenuhan hajat/keinginan. Ini terdiri dari bisnis jasa dan industri. Demikian lebih kurang yang dipaparkan alMawardi ${ }^{1}$.

Karena beribadah dan kekhalifahan di dunia adalah tujuan penciptaan manusia sekaligus kewajiban yang harus dilaksanakannya (QS. Al-Baqarah 2:30 dan QS. Adz-Dzariyat 51: 56), sedang ibadah tidak dapat terlaksanakan dengan baik kecuali bila manusia memenuhi kebutuhan hidupnya, maka pemenuhan hidup itu merupakan kewajibannya baginya karena "sesuatu yang wajib, yang tidak dapat terlaksanakan kecuali melalui hal lain, maka hal lain itu menjadi wajib pula". Selanjutnya, karena pemenuhan ini pada dasarnya tidak dapat diraih kecuali dengan bekerja dan berusaha, maka bekerja dan berusaha merupakan kewajiban. Di sisi lain, karena kekhalifahan adalah tujuan kehadiran manusia, maka tujuan ini diharuskan juga adanya upaya, usaha, dan kegiatan positif manusia. Kalau seseorang tidak dapat memenuhi kebutuhan hidup/keinginannya kecuali dengan bantuan orang lain, maka sangat wajar jika orang lain itu menerima imbalan atas jasanya membantu, karena kalau tidak, yang mengambilnya tanpa imbalan dapat dinilai menganiaya (Afrida 2018).

Lebih jauh, manusia yang bekerja menurut al-Mawardi tidak keluar dari tiga kategori: (1) Berusaha memenuhi kebutuhan hidupnya dengan cukup dan cukup saja, tanpa berusaha meraih yang melebihi kebutuhannya dan tidak juga kurang darinya. Katakanlah hasil yang diusahakan dan diperjuangkannya adalah pas-pasan. (2) Berusaha, tetapi mengabaikan sebagian potensi-nya. Pengabaian ini bias jadi karena malas, tawakkal, dan zuhud atau mengabaikan kenikmatan duniawi demi mendekatkan diri kepada Allah. Yang malas, kehilangan peluang meraih nikmat bekerja dan nikmat sukses dan ini dapat mengantarnya menjadi beban buat masyarakat. Yang bertawakkal sehingga mengabaikan sebagian potensinya pada hakikatnya adalah manusia lemah, lalu menggunakan dalih untuk menghibur dirinya, serta mengabaikan sesungguhan dengan mengganti namanya dengan tawakkal. Sebab tawakkal tidak diperintahkan Allah sebelum memerintahkan terlebih dahulu bekerja secara maksimal dan setelah habisnya segala daya upaya. Adapun yang mengabaikan sebagian potensinya dengan alasan zuhud, maka dia boleh jadi berhitung tentang beratnya tanggung jawab kepemilikan harta serta terdorong oleh takut akan dampak-dampak buruk kepemilikan itu karena itu dia memilih untuk miskin keimbang kaya. (3) Tidak puas dengan kecukupan dan selalu berkeinginan untuk meraih tambahan yang banyak. Sikap ini biasanya lahir karena salah satu dari empat sebab: (a) Menentang hawa nafsu yang dinilainya tidak dapat dibendung kecuali dengan memenuhi keinginan nafsu itu, dan ini dilakukan melalui kepemilikan harta yang banyak. (b) Agar dengan perolehan harta yang banyak ia dapat melakukan banyak kegiatan positif /kebajukan. Inilah yang terbaik dan merupakan anjuran agama. (c) Menabung untuk anak cucu. Yang bersangkutan bisa mengorbankan dirinya demi anak cucunya. Sikap semacam ini sangat buruk jika melampai batas. Salah satu keburukannya adalah ketiadaan sangka baik kepada Allah SWT. (d) Berusaha sakuat tenaga melalui persaingan tidak sehat dengan tujuan pamer dan berbangga-

\footnotetext{
${ }^{1}$ Lihat selengkapnya Abuhasan Ali Bin Muhammad al-Bashri al-Mawardi dalam Adab Ad-Dunya Wa AdDin, (Beirut: Dar Al- Kutub Al Ilmiyah, 1987), hlm 185-186. Selanjutnya disebut Adab Ad-Dunya
} 
bangga guna menunjukan kehebatan dan keunggulannya. Inilah yang terburuk, semua kecaman tertuju kepadanya sehingga menjadi bencana atasnya.

Kepemilikan yang banyak tidak dilarang oleh agama, bahkan baik untuk memiliki yang lebih banyak. Tetapi jika tidak berhati-hati maka seseorang dapat terjerumus, oleh karena itu agama memberi rambu-rambu serta petunjuk agar kepemilikan harta tidak membawa bencana. Tidak juga hanya menguntungkan satu pihak atau golongan dan mengakibatkan kerugian pasti bagi yang lain. Harta harus beredar sehingga menyentuh banyak orang dan tidak beredar dikalangan yang berpunya saja. Di samping ketentuan-ketentuan hukum yang mengikat ada juga ketentuan-ketentuan akhlak yang hendaknya menjadi perhatian setiap pemilik harta (Widyatma 2014).

\section{Kacamata Islam Memandang Harta Dan Bisnis}

Nabi Muhammad SAW. sebelum diangkat menjadi Nabi dan berkosentrasi menyampaikan dahwah islam, melakukan aneka kegiatan bisnis. Setelah menjadi nabi beliau tetap menganjurkan agar umatnya melakukan kegiatan tersebut. Ini karena memang Al-Quran menganjurkan itu (Saifullah 2011).

Al-Qur'an menguraikan sekian banyak kegiatan bisnis, bahkan kitab suci itu menggunakan istilah-istilah bisnis dalam interaksi manusia dengan Tuhan. Sementara orang menduga bahwa harta yang menjadi dambaan setiap pebisnis bukanlah sesuatu yang mendapatkan tempat istimewa dalam ajaran Islam. Pandangan ini sungguh keliru! Sungguh Al-Quran memberi perhatian dan mendorong umat islam untuk mencari harta. Perhatian dan dorongan itu dapat terlihat antara lain pada: (a) Jumlah pengulangan kata maal/harta dalam Al-Quran sebanyak 85 kali, seimbang bahkan lebih banyak dari pada pengulangan kata-kata nabi yang terulang 80 kali. (b) Penamaan harta yang banyak dengan al-Khair yang secara harfiah berarti baik (QS.Al- Baqarah 2: 180) atau perintah menjadi fadhl yang secara harfiah berarti kelebihan bukan sekedar kecukupan (baca antara lain QS. Al- Jumu'ah 62: 9-10), serta penamaan harta dan anak-anak sebagai zinat al-hayat ad-dunya atau hiasan kehidupan dunia (QS. Al- Kahfi 18: 46). (c) Penegasan bahwa harta adalah qiyaman lin-nas atau pokok kehidpan manusia (QS. An- Nisa 4: 5). (d) Perintah mengembangkan harta anak yatim sehingga dapat membiayai hidup mereka dari keuntungan pengembangan, bukan dari modal (QS. An- Nisa 4: 5). (e) Perintah menulis utang piutang walau sedikit agar harta tidak hilang dan tidak terjadi silang pendapat (QS. Al-Baqarah 2: 282). (f) Penganugerahan naluri mencintai harta benda (QS. Ali-Imran 3:4). Itu semua dan sekian lainnya dilakukan oleh Al-Quran karena Allah SWT. Menciptakan manusia untuk menjadi khalifah yang bertugas memakmurkan bumi ini (QS. Hud 11: 61) (Departemen Agama RI 2010).

Kemakmuran bumi dan melaksankannya fungsi kekhalifahan bahkan beribadah secara baik apalagi meraih kejayaan tidak dapat dilaksanakan tanpa harta benda dan kesucian jiwa. Dengan kata lain unsur materi itu dikenal doa yang menyatakan: "Allahumma Hablii Hamdan wa Majdan wa laa Majda Illa bifi'alin wa laa fi'ala illa bi Maalin, walaa Maala Illa bi Amalin", artinya: Ya Allah anugerahilah aku pujian (nama baik) dan kejayaan. Tiada kejayaan tanpa perbuatan dan tiada perbuatan tanpa harta dan tidak ada harta tanpa kerja.

Al- Qur'an telah mengajarkan agar umat islam memohon dengan terucap:

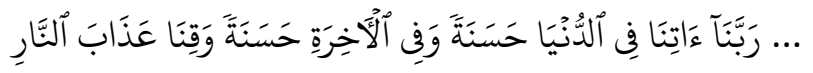


Artinya: Tuhan kami. Anugerahilah kami kebaikan di dunia dan kebaikan di akhirat dan hindarkanlah kami dari siksa api neraka" (QS. Al-Baqarah 2:201). Tidak ditemukan celaan menyangkut harta dan upaya memilikinya kecuali bila meraihnya dengan cara yang tidak sah, dan bila ia melengahkan pemiliknya, atau bila ia digunakan secara batil.

Dari sini Islam memperingati manusia agar tidak terpedaya olehnya. AlQuran mengingatkan bahwa:

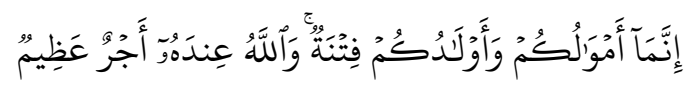

Artinya: "Harta Benda dan anak-anak kamu tidak lain kecuali ujian, sedangkan di sisi Allah Terdapat ganjaran yang agung”(QS. At-Taghabun 64: 15). Rasul SAW. juga bersabda: "Setiap umat ada bahan ujiannya dan bahan ujian umatku adalah harta benda. (HR. At-Tirmidzi melalui Ka'ad bin 'Iyadh).

Atas dasar ini, Al-Quran dan Sunnah menetapkan ketentuan-ketentuan yang dapat menjamin siapa yang mengindahkannya untuk tidak terjerumus dalam kesulitan duniawi dan ukhrawi bahkan menjamin kesejahteraan dan kebahagiaannya dunia akhirat. Tentu saja tidak semua kegiatan ekonomi/bisnis dirinci oleh Al-Quran. Karena persoalan ini sangat luas dan berkembang dari masa ke masa. Atas dasar itu, Al-Quran memberi tuntunan umum berupa prinsipprinsip dasar yang dapat dijabarkan umat sepanjang masa sesuai dengan kebutuhan, serta kondisi social dan perkembangan masyarakatnya (Hidayatulloh 2012).

\section{Bisnis Dalam Pandangan Islam}

Ekonomi dan praktik bisnis islam berkaitan sangat erat dengan akidah dan syariat Islam sehingga seseorang tidak akan memahami pandangan islam tentang ekonomi dan bisnis tanpa memahami dengan baik akidah dan syariat Islam. Keterikatan dengan akidah atau kepercayaan menghasilkan pengawasan melekat pada dirinya dengan mengindahkan perintah dan larangan Allah yang tercemin pada kegiatan halal dan haram. Ini juga mendorong penerapan akhlak sehingga terjalin hubungan harmonis dengan mitranya yang pada gilirannya akan mengantar kepada lahirnya keuntungan bersama, bukan sekedar keuntungan sepihak (Rujiansyah 2017).

Selanjutnya, bisnis atau ekonomi bahkan semua ilmu dalam pandangan Islam dalam operasionalnya berpijak pada dua area: (1) Prinsip-prinsip dasar yang ditetapkan oleh Al-Quran dan Sunnah, dan ini bersifat langgeng abadi tidak mengalami perubahan. (2) Perkembangan positif masyarakat, ilmu pengetahuan dan teknologi, dimana terbuka lapangan yang luas untuk menampung yang baru lagi baik dari hasil pemikiran dan budi daya manusia dan itu berarti dia bersifat sementara karena bila ada sesuatu yang lebih baik dimana pun ditemukan maka itu harus menggantikan tempat yang lama yang tidak sebaik itu (Qaradhawi 1997).

Jangan menduga bahwa adanya pronsip dasar bagi kegiatan ekonomi dan bisnis hanya terbatas pada ajaran islam. Setiap aliran ekonomi selalu berpijak pada prinsip-prinsip dasar yang menjadi rujukan penganutnya sehingga mengarahkan setiap langkah dalam bekerja dan berproduksi. Kapitalisme misalnya, yang menganut paham kebebasan termasuk dalam bidang ekonomi dan bisnis tentu memiliki pandangan atau kepercayaan dalam hal kebebasan yang berbeda dengan pandangan komunisme yang juga dalam bidang ekonomi 
diarahkan oleh pandangan mereka tentang gerak sejarah dan materialism. Demikian terlihat bahwa upaya peningkatan ekonomi dan bisnis bukan sekedar persoalan ekonomi, tetapi juga berpijak pada prinsip-prinsip kepercayaan, polotik, budaya, bahkan akhlak dan lain-lain.

Berbicara tentang prinsip dasar yang dianut oleh ajaran islam, dapat dikatakan bahwa inti ajarannya adalah Tauhid. Dari sini lahir ketentuan-ketentuan yang bukan saja berkaitan dengan ekonomi/bisnis, tetapi juga menyangkut segala aspek kehidupan dunia dan akhirat. Tauhid dapat diibaratkan dengan matahari. Kalau di alam raya ini ada matahari yang diciptakan Allah menjadi sumber kehidupan makhluk di permukaan bumi ini dan di sekitarnya berkeliling planetplanet tata surya yabg tidak dapat melepaskan diri darinya, seperti kesatuan hukum keadilan dan kemaslahatan, dan lain-lain (Azimi 2009).

Tauhid melahirkan keyakinan bahwa segala sesuatu bersumber dari Allah dan berkesudahan kepada-Nya. Dialah pemillik mutlak dan tunggal yang dalam genggaman-Nya segala sesuatu, termasuk kepemilikan harta dan kewenangan menetapkan aturan pengelolaan dan pengembangannya. Dan kerena Allah Maha adil dan selalu memerhatikan kemaslahatan umat manusia. Maka semua ketetapan hukum-Nya, demikian juga produk ijtihad manusia yang dikaitkan dengan namaNya, tentulah harus bercirikan keadilan dan kemaslahatan. Bisa jadi ada ketentuan hukum yang dilarang atau enggan ditetapkan pada satu masa karena ketika itu dinilai bertentangan dengan kemaslahatan, tetapi karena adanya perkembangan masyarakat, maka ketetapan tersebut dicabut atau dirubah pada masa lainnya. Sehingga lahir ungkapan: "dimana ada kemaslahatan disanalah terdapat hukum Allah".

Kesatuan kemanusiaan mengantar pengusaha muslim menghindari segala bentuk eksploitasi terhadap sesama umat muslim atau non-muslim. Dari sini dapat dipahami mengapa Islam mengharamkan bukan riba, tetapi juga penipuan atau apa yang diduga dapat mengakibatkan penipuan walau terselubung. Kesatuan kemanusiaan mengharuskan manusia berpikir dan mepertimbangkan kepentingan umat manusia seluruhnya dalam semua tindakannya, bukan hanya untuk generasinya, tetapi juga generasi mendatang, sehingga terhindar dari penggunaan dan pemanfaatan sumber daya alam berlebihan oleh generasi masak kini saja (Febriyarni 2016).

Keyakinan akan kesatuan dunia akhirat, mengantar seseorang untuk memiliki visi yang jauh kedepan, dan tidak hanya berupaya mengejar keuntungan duniawi semata. Dari sini pula Al-Quran mengingatkan bahwa sukses yang diperoleh mereka yang berpandangan dekat, bias melahirkan penyesalan dan bahwa kelak di masa depan mereka akan merugi dan dikecam (QS. Al- Isra 17: 18-19).

Selanjutnya, secara umum dapat dikatakan bahwa ketentuan-ketentuan yang ditetapkan Al-Quran dalam konteks berbisnis, paling tidak dapat dikelompokkan menjadi tiga kelompok besar: (a) berkaitan dengan hati atau kepercayaan pebisnis, (b) berkaitan dengan moral dan prilaku pebisnis, (c) berkaitan dengan pengembangan harta atau keuntungan (Latif 2014).

\section{Syarat-Syarat Berbisnis Dalam Islam}

Berbisnis dalam Islam tentu saja memiliki syarat-syarat tertentu. Namun satu hal yang harus diperhatikan bahwa dalam bisnis antar sesama manusia 
terjalin hubungan timbal balik. Antara satu dengan yang lainnya. Penjual tentu membutuhkan antara satu dengan yang lainnya. Penjual tentu membutuhkan pembeli, debitur memerlukan kreditur, dan seterusnya. Hubungan timbal balik yang meniscyakan kesetaraan ini membuat kerjasama mungkin dilakukan.

Tetapi ketika menyebut berbisnis dalam Islam sama seperti kita berbisnis dengan Allah, tidaklah pantas hubungan yang saling membutuhkan ini berlaku. Sungguh Allah tidak membutuhkan manusia untuk berbisnis dengan-Nya. Tidak juga dikatakan hubungan dengan Allah kita setara atau sejajar. Tetaplah Allah yang Maha Tinggi, Maha Berkuasa dan Maha Menentukan. Manusia tetap saja sebagai hamba atau makhluk ciptaan-Nya. Diri, harta dan ibadah manusia hanya untuk Allah semata (Akbar 2012).

Tentu saja agar transaksi bisnis dengan Allah dapat berlangsung dengan baik, maka ada beberapa persyaratan yang harus di penuhi. Persyaratan yang sifatnya mutlak yaitu: (1) Percayalah kepada Allah, kata lain dari percaya adalah beriman kepada Allah. Pertanyaan sederhananya adalah mungkinkah kita membangun kerja sama bisnis dengan orang yang sama sekali kita tidak percayai. Perampok dan pencuri sekalipun tetap saja mencari orang yang amanah lagi jujur untuk menyimpan hartanya. Kepercayaan sesungguhnya satu hal yang mutlak ada dalam bisnis. (2) Tidak merasa terpaksa, Allah tidak pernah memaksa hambanya untuk beriman kepada Allah. Didalam Al-Quran Allah menyebutkan bahwa "siapa yang ingin beriman, silakan beriman dan barang siapa yang ingin kufur, silahkan kufur”. Berimannya seluruh manusia diseluruh alam ini tidak akan mengkayakan Allah. Kufurnya seluruh manusia juga tidak membuat Allah miskin. Allah tidak memiliki kepentingan sedikitpun kepada manusia. Berbisnis dengan Allah tidak boleh dengan keadaan terpaksa, oleh sebab itu, Islam sendiri alinqiyad dan al-khudu' (tunduk dan pasrah) kepada Allah. Orang yang memeluk Islam sama maknanya ia telah memasrahkan dirinya secara sukarela kepada Allah dan kepada semua ketentuan-ketentuannya. (3) Ikhlas dalam berbisnis dengan Allah, dalam bahasa bisnis ini berarti apa yang dijual itu benar-benar dijual kepada-Nya semata, tidak kepada selain-Nya atau menyertakan selain-Nya dalam kepemilikan komoditas yang dijual. Dalam Al-Quran Allah berfirman:

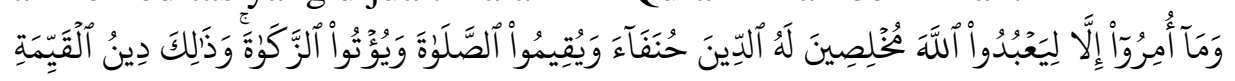

Artinya: "Padahal mereka tidak disuruh kecuali supaya menyembah Allah dengan memurnikan ketaatan kepada-Nya dalam (menjalankan) agama yang lurus, dan supaya mereka mendirikan shalat dan menunaikan zakat; dan yang demikian itulah agama yang lurus" (QS. Al-Bayyinah 98:5).

Sungguh Allah pada hakikatnya tidak pernah menginginkan keburukan kepada hambanya. Andaipun merasakan kepedihan, kesusahan dan penderitaan, itu juga dalam rangka kasih sayang Allah. Manusia tidak perlu berprasangka buruk kepada Allah. Sebaliknya, sikap yang perlu dikembangkan adalah sikap pasrah dan tunduk dengan penuh keikhlasan dalam melakukan aktivitas apapun dimuka bumi ini. Ketulusan itu la yang mendapat tepat disisi Allah. Pada akhirnya, pebisnis yang ikhlas akan dimudahkan Allah segala usahanya untuk mencari keberkahan didunia dan diakhirat (Khoiruddin 2013).

\section{Memaknai Cinta Kepada Allah}

Cinta kepada Allah merupakan konsekuensi keimanan. Tidak akan sempurna tauhid kepada Allah hingga seorang hamba mencintai Tuhannya secara 
sempurna. Kecintaan tidak bisa didefinisikan dengan lebih jelas kecuali dengan kata kecintaan itu sendiri. Dan tidak bisa disifatkan dengan yang lebih jelas seperti kata kecintaan itu sendiri. Tidak ada sesuatu yang esensinya patut dicintai dari segala sisi selain Allah, tidak boleh ada sesembahan, peribadatan, ketundukan dan kepatuhan serta kecintaan yang sempurna kecuali hanya kepada Allah.

Cinta kepada Allah, bukanlah sembarang cinta; tidak ada suatu apapun yang lebih dicintai dalam hati seseorang selain Sang Penciptanya. Dialah Tuhannya, Sesembahannya, Pelindungnya, Pengayomnya, Pengaturnya, Pemberi rezekinya, dan Pemberi hidup dan matinya. Maka mencintai Allah merupakan kesejukan hati, kehidupan jiwa, kebahagiaan sukma, hidangan batin, cahaya akal budi, penyejuk pandangan dan pelipur lara. Tiada satupun menurut hati yang bersih, sukma yang suci, pikiran yang jernih, lebih indah, lebih nyaman, lebih lezat, lebih menyenangkan dan lebih nikmat dari pada kecintaan kepada Allah, perasaan tenteram damai disisi-Nya dan kerinduan akan berjumpa denganNya (Masroom, Muhamad, and Panatik 2013).

Hakikat dari cinta adalah bagaimana merelakan segala sesuatu yang dimiliki untuk seseorang yang dicintai sehingga tidak menyisakan sedikitpun pada dirinya. Maka kecintaan seseorang kepada Allah hendaklah mengalahkan segala perkara sesuatu yang dicintai, sehingga apapun yang dicintai oleh seseorang maka akan tunduk kepada cinta yang menjadi penyebab kebahagiaan dan kesuksesan bagi dirinya. Kadar kecintaan dalam hati orang yang mencintai Allah adalah bertingkat-tingkat. Itulah sebabnya, Allah menggambarkan betapa besarnya kecintaan orang-orang mukmin kepada-Nya:

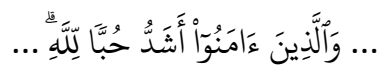

Artinya: “... Orang-orang yang beriman sangat mendalam cintanya kepada Allah...”. (QS Al-Baqarah 2: 165).

Cinta kepada Allah berarti mengutamakan segala sesuatu yang disukai Allah diatas diri, jiwa dan harta bendanya, lalu ketaatan kepada Allah dalam kesendirian dan keramaian, kemudian sadar akan kelalaian dalam mencintai Allah. Seharusnya secara totalitas mencintai Allah dengan mencurahkan jiwa dan raga serta hati dalam mencari Sang Kekasih, dengan lisan yang selalu bergerak untuk menyebut nama-Nya (At-tamimi 2000).

Rasulullah bersabda: "Aku memohon kepada-Mu agar dapat mencintai$M u$, mencintai orang-orang yang mencintai-Mu dan mencintai amal yang mendekatkan diriku untuk mencinta-Mu”. Suatu kecintaan yang apabila telah melekat dihati, akan menjadi al-Walah (peribadatan), dan al-Walah adalah kecintaan yang sangat dalam. Karenanya ketundukan dan peribadatan kepada Allah adalah bentuk kecintaan yang dalam kepada Allah dan kecintaan terhadap sesuatu yang datang dari sisi Allah.

Diantara indikasi cinta kepada Allah adalah mencintai orang-orang yang taat kepada Allah, loyal kepada wali-wali Allah, dan memusuhi orang-orang yang membangkang kepada-Nya, berjihad melawan musuh-musuh-Nya dan menolong para penolong-Nya. Semakin kuat kecintaan hamba kepada Allah maka semakin kuat pula praktik amal-amalnya.

Diantara sebab yang mendatangkan kecintaan kepada Allah adalah mengenal Allah melalui nama-namaNya yang terindah dan sifat-sifatNya serta perbuatan-perbuatanNya. Siapa yang mengenal Allah maka dia akan mencintai Allah, siapa yang mencintai Allah maka ia akan taat kepadaNya, siapa yang taat 
kepada Allah maka Allah akan memuliakannya, dan siapa yang dimuliakan Allah maka Allah akan menempatkannya disisiNya, dan siapa yang ditempatkan oleh Allah di sisi-Nya maka sungguh beruntunglah nasibnya.

Diantara penyebab utama cinta kepada Allah adalah merenungkan tentang kerajaan-Nya di langit dan di bumi. Semua yang Allah ciptakan merupakan tandatanda yang melambangkan keagungan-Nya, kemaha-kuasaan-Nya, kemuliaanNya, kesempurnaan-Nya, keperkasaan-Nya, kelembutan dan kasih sayang-Nya, dan nama-nama Allah yang demikian indah serta sifat-sifatNya yang luhur lainnya. Maka semakin kuat makrifat (pengenalan) hamba tentang Allah, maka semakin kuat pula rasa cintanya kepada Allah dan kecintaannya untuk mentaatiNya.

Diantara penyebab yang mendatangkan kecintaan kepada Allah adalah bersikap tulus dan ikhlas dalam bermu'amalah dengan Allah, serta tidak menuruti kemauan hawa nafsu. Hal ini merupakan penyebab turunnya karunia Allah kepada hambaNya sehingga anugerah cinta kepada-Nya dapat diraih (Shafik and Bakar 2014).

Ada empat bentuk kecintaan yang harus dibedakan satu dengan yang lainnya: (1) Kecintaan kepada Allah, kecintaan ini semata tidak cukup untuk menyelamatkan seseorang dari azab Allah dan meraih ganjaran dari pada-Nya. Karena kaum musyrikin, para penyembah salib, kaum yahudi, dan yang lainnya juga mencintai Allah. (2) Mencintai apa yang dicintai oleh Allah, dan kecintaan inilah yang memasukan seseorang ke dalam Islam dan mengeluarkannya dari kekufuran. Sedangkan orang yang paling dicintai oleh Allah adalah yang paling mampu mengaplikasikan kecintaan ini dan yang paling konsisten menjalankannya. (3) Cinta di jalan Allah dan karena Allah. Maka inilah konsekuensi dari mencintai apa yang dicintai oleh Allah, yang mana tidak akan lurus kecintaan apa yang dicintai oleh Allah kecuali melalui cinta di jalan-Nya dan karenaNya. (4) Mencintai selain Allah disamping cinta kepada Allah, inilah cinta kesyirikan. Maka semua yang mencintai sesuatu yang lain bersamaan dengan kecintaan kepada Allah, bukan karena Allah, dan bukan juga di jalan Allah, maka ia telah menjadikannya sebagai teman atau tandingan bagi Allah. Inilah bentuk kecintaan kaum musyrikin (Luthfi 2003).

\section{Sifat dan Perilaku yang Disukai Allah}

Dalam menjalani hidup, manusia harus menjadikan Allah sebagai tujuan dengan senantiasa mengharap ridha-Nya dan menjadikan surga sebagai cita-cita. Demikian juga kesuksesan. Untuk mencapai kesuksesan dunia dan akhirat, tentu kita harus senantiasa mendekatkan diri pada Allah dan menjadi orang yang berada dalam perintahNya. Berikut ini sifat atau perilaku manusia yang disukai oleh Allah berdasarkan dalil dalam Al-Quran yaitu: Al-Muhsinin, Al-Muttaqin, AlMuqsithin, Al-Mutathahhirin, At-Tawwabin, Ash-Shabirin, Al-Mutawakkilin (Maryatin 2017).

Dalam berusaha dan berserah kepada Allah, tentu manusia tidak boleh hanya duduk menunggu jawaban atau keajaiban. Manusia perlu terus berdoa mendekatkan diri kepada Allah. Agar benar-benar diberikan yang baik sesuai keinginan dan baik menurut Allah, hal lain yang bisa dilakukan adalah seperti: memperbanyak sedekah, shalat tahajud, dan memperbanyak silaturahmi, selain 
itu, tentu masih banyak amalan lainnya. Jika dikerjakan secara istiqamah, insya Allah akan mempermudah segala urusan dan cita-cita makhluk-Nya.

Dalam Al-Qur'an Allah berfirman:

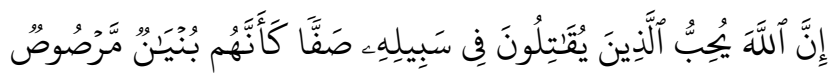

Artinya: "Sesungguhnya Allah menyukai orang yang berperang dijalan-Nya dalam barisan yang teratur akan mereka seperti suatu bangunan yang tersusun kokoh”. (QS. Ash-Shaf 61: 4). Ayat tersebut menunjukkan perlunya kebersamaan, jaringan dan koordinasi. Ciri khas ajaran Islam adalah kebersamaan dalam segala aktivitas positif, baik dalam melaksanakan ritual ibadah dalam melaksanakan aneka aktivitas, seperti shalat berjamaah lebih utama daripada shalat sendirian. Di sisi lain, kebersamaan itu tidak harus menjadikan semua pihak melakukan satu pekerjaan yang sama, tetapi perlu pembagian kerja yang diatur dalam satu jaringan yang baik.

Ada empat sifat khusus yang disebut salam surat Al-Maidah: 54 yang menjadi sebab tercurahnya cinta Allah kepada manusia, yaitu: (a) lemah lembut terhadap orang-orang mukmin, (b) mulia atau memiliki harga diri dan tegas terhadap yang kafir, (c) berjihad di jalan Allah, dan (d) tidak takut kepada celaan pencela. Surat Ali Imran ayat 31 dan 32 memberi gambaran yang sangat umum, siapa atau perbuatan apa yang paling Allah sukai, yakni perintah untuk menaati Allah dan Rasul-Nya. Al-ittiba' berarti meneladani, mengikuti secara sungguhsungguh. Cinta Allah yang luar biasa akan diraih oleh mereka yang bersungguhsungguh mengikuti Nabi Muhammad SAW. Al-ittiba' yang dimaksud dalam sabda Rasul SAW. yang artinya: "yakni atas dasar kebajikan, takwa, dan rendah hati" (HR at-Tirmidzi, Abu Nu'aim, dan Ibnu 'Asakir melalui sahabat Nabi, Abu adDarda).

Ibnu Sina (980-1037M) mengemukakan tiga kelompok manusia dalam bermuamalah/berinteraksi dengan Allah antara lain: (1) Seorang yang banyak beribadah, tetapi semata-mata karena takut tersiksa dalam neraka. Yang semacam ini, menurutnya, layaknya sebagai hamba sahaya, yang tidak bekerja dengan baik kecuali akibat rasa takutnya kepada tuannya. Orang semacam ini dinamai 'abid. (2) Seseorang yang berpaling dari kenikmatan duniawai, kendati ia menyukainya. Dia adalah yang bersedia bersakit-sakit dahulu agar bersenang-senang kemudian. Ini menurutnya adalah sikap pedagang yang berbisnis dengan Allah. (3) Seseorang yang berpikir tentang untung-rugi, senang dan susah. Dia melakukan apa yang diperintahkan dan menjauhi apa yang dilarang semata-mata demi cintanya kepada Allah, layaknya seorang ibu ketika mengasuh anaknya. Harus diakui bahwa motivasi memperoleh imbalan atas ibadah yang dilakukan adalah menjauhkan diri dari neraka dan mendapatkan surga, hal tersebut tidak dilarang oleh Al-Quran dan Sunnah, tetapi bukanlah motiovasi tertinggi. Motivasi tertinggi adalah butir ketiga yang disebut Ibnu Sina (Shihab 2011).

Dalam Al-Quran Allah telah menjelaskan bahwa tentang perniagaan denganNya untuk manusia, dimana Al-Quran telah memberikan pelajaran kepada setiap insan yang ingin melaksanakan jual-beli, baik jasa, maupun barang atau menempuh hal serupa dalam melakukan bisnis sesama manusia. Disamping itu, ada juga tempat-tempat dan waktu dimana diadakan, yakni memperoleh sesuatu yang berharga dengan pembayaran yang sangat murah. Seperti bulan Ramadhan, ada lailatul Qadar, ada tempat suci Mekkah, Madinah, Masjidil Al-Aqsha dan 
lain-lain, dimana waktu dan tempat itu, dapat memperoleh anugerah yang tidak dapat diperoleh pada waktu dan tempat lainnya (Adzkiya' 2017).

\section{KESIMPULAN}

Kunci sukses adalah iman, iman merupakan fondasi dalam beramal saleh sebab Allah hanya akan menerima amal saleh makhluk yang beriman kepada-Nya. Kemampuan beramal saleh inilah yang dapat dikatakan sebagai kesuksesan dunia dan akhirat. Dalam hadits Nabi diriwayatkan bahwa "Sebaik-baik manusia adalah yang paling bermanfaat bagi manusia lainnya" ini merupakan landasan pokok bagi manusia untuk menyikapi kesuksesan. Sejatinya, semakin tinggi kesuksesan yang diraih, semakin besar pula tanggung jawab yang dilakukan. Semakin tinggi pendidikan yang diperoleh, semakin besar amanah untuk menyampaikannya kepada orang lain. Semakin banyak kekayaan yang didapat, semakin banyak zakat maal dan sedekah yang harus dikeluarkan untuk orang lain. Kemakmuran bumi dan melaksanakan fungsi kekhalifahan dan juga beribadah secara baik apalagi meraih kejayaan tidak dapat dilaksanakan tanpa harta benda dan kesucian jiwa. Oleh sebab itu Islam memperingati manusia agar tidak terpedaya olehnya. AlQuran mengingatkan bahwa: "Harta Benda dan anak-anak kamu tidak lain kecuali ujian, sedangkan disisi Allah Terdapat ganjaran yang agung" (QS. At-Taghabun 64: 15). Rasul SAW. juga bersabda: "Setiap umat ada bahan ujiannya dan bahan ujian umatku adalah harta benda" (HR. At-Tirmidzi melalui Ka'ad bin 'Iyadh). Atas dasar ini, Al- Qur'an dan Sunnah menetapkan ketentuan-ketentuan yang dapat menjamin siapa yang mengindahkannya untuk tidak terjerumus dalam kesulitan duniawi dan ukhrawi bahkan menjamin kesejahteraan dan kebahagiaannya dunia akhirat.

\section{DAFTAR PUSTAKA}

Adzkiya', Ubbadul. 2017. "Analisis Etika Bisnis Dan Marketing Nabi Muhammad SAW.” IQTISAD 4 (1): 1-23. https://doi.org/10.31942/iq.v4i1.2000.

Afrida, Afrida. 2018. "Hakikat Manusia Dalam Perspektif Al-Qur`an.” Al-Qisthu: Jurnal Kajian Ilmu-Ilmu Hukum 16 (2): 54-59. https://doi.org/10.32694/010510.

Akbar, Ali. 2012. “Konsep Kepemilikan Dalam Islam.” Jurnal Ushuluddin 18 (2): 124-40. https://doi.org/10.24014/jush.v18i2.704.

Aldy, Rochmat, Purnomo Riawan, and La Ode Sugianto. 2017. Studi Kelayan Bisnis. Ponorogo: Unmuh Ponorogo Press.

Amalia, Fitri. 2013. "Etika Bisnis Islam: Konsep Dan Implementasi Pada Pelaku Usaha Kecil.” Al-Iqtishad: Jurnal Ilmu Ekonomi Syariah 6 (1): 116-25. https://doi.org/10.15408/aiq.v6i1.1373.

Arifin, Johan. 2008. "Dialektika Etika Islam Dan Etika Barat Dalam Dunia Bisnis." Millah: Jurnal Studi Agama 8 (1): 145-68. https://doi.org/10.20885/millah.vol8.iss2.art9.

Aryadi. 2018. "Bisnis Dalam Islam." Jurnal Hadratul Madaniyah 5 (1): 13-26.

At-tamimi, Syaikh Muhammad. 2000. Kitab Tauhid. Kitab Tauhid. Jakarta: 
Yayasan Al-Sofwa.

Azimi, Zul. 2009. "Studi Islam Komprehensif." Jurnal Mentari: Jurnal Ilmiah Ilmu-Ilmu Humaniora 12 (1).

Departemen Agama RI. 2010. Al Qur'an Dan Tafsirnya. Jakarta: Departemen Agama RI.

Djakfar, Muhammad. 2008. Etika Bisnis Islami: Tataran Teoritis Dan Praktis. Malang: UIN-Maliki Press.

Febriyarni, Busra. 2016. "Fiqh Al-Hadis Etika Bisnis (Tinjauan Kesahihan Dan Pemahaman)." Al Istinbath: Jurnal Hukum Islam 1 (2): 141-60.

Heriyansyah, Heriyansyah. 2018. "Perjalanan Bisnis Nabi Muhammad S.A.W." Ad Deenar: Jurnal Ekonomi Dan Bisnis Islam 2 (02): 190-205. https://doi.org/10.30868/ad.v2i02.356.

Hidayatulloh, Haris. 2012. "Etika Bisnis Dalam Prespektif Al-Qur'an: Upaya Membangun Bisnis Yang Islami Untuk Menghadapi Tantangan Bisnis Di Masa Depan.” In Prosiding Seminas.

Holle, Mohammad H. 2019. "Implementasi Etika Islam Dalam Berbisnis." Ekonomi Syariah 1 (1): 1-29.

Khoiruddin, Khoiruddin. 2013. "Implementasi Etika Bisnis Perspektif Islam." Muqtasid: Jurnal Ekonomi Dan Perbankan Syariah 4 (2): 1-16. https://doi.org/10.18326/muqtasid.v4i2.311-333.

Khuza'i, Rodliyah. 2005. "Etika Bisnis Dalam Persektif Islam.” Mimbar: Jurnal Sosial Dan Pembangunan 21 (1): 36-48.

Latif, Umar. 2014. "Al-Quran Sebagai Sumber Rahmat Dan Obat Penawar Bagi Manusia." Jurnal Al-Bayan: Media Kajian Dan Pengembangan Ilmu Dakwah 20 (2): 77-88.

Ludin, Ismail, Suherman Saleh, and Dedeng Abdul Gani Amruloh. 2018. "Pengaruh Kecerdasan Intelektual, Kecerdasan Emosional, Dan Kecerdasan Spiritual Terhadap Kinerja Wirausaha Muslim Di Kabupaten Purwakarta." E-Qien: Jurnal Ekonomi Dan Bisnis 5 (1): 8-18. https://doi.org/10.34308/eqien.v5i1.10.

Luthfi, M. 2003. "Membumikan Al-Qur'an." ALQALAM: Jurnal Kajian Keislaman 20 (98-99): 21-40. https://doi.org/10.32678/alqalam.v20i9899.634.

Maryatin. 2017. "Akhlak Tasawuf.”

Masroom, Mohd Nasir, Siti Norlina Muhamad, and Siti Aisyah Panatik. 2013. "Iman, Islam Dan Ihsan: Kaitannya Dengan Kesihatan Jiwa." In Semianar Pendidikan \& Penyelidikan Islam Kali Pertama, 582-590. Johor Bahru: Assosiation of Islamic Education Scholars.

Miftah, Ahmad. 2015. "Mengenal Marketing Dan Marketers Syariah." ISLAMICONOMIC: Jurnal Ekonomi Islam 6 (2): 15-20. https://doi.org/10.32678/ijei.v6i2.56.

Qaradhawi, Yusuf. 1997. Norma Dan Etika Ekonomi Islam. Jakarta: Gema Insani Press.

Rangkuti, Freddy. 2005. Analisis SWOT: Teknik Membedah Kasus BisnisOrientasi Konsep Perencanaan Strategis Untuk Menghadapi Abad 21. Jakarta: Gramedia Pustaka Utama.

Rujiansyah, Rujiansyah. 2017. "Etika Bisnis Dalam Islam." Jurnal Ekonomika: Manajemen, Akuntansi, Dan Perbankan Syari'ah 4 (1): 1-11. 
https://doi.org/10.24903/je.v4i1.209.

Sagita, Rita, and Herlina. 2015. "Sistem Freewebstore UKM Keripik Pisang FG Berbasis Teknologi Di Pekon Gemahripah Kec. Pagelaran Kab. Pringsewu." Jurnal Teknologi Informasi Dan Bisnis Pengabdian Masyarakat Darmajaya 1 (2): 45-56.

Saifullah, Muhammad. 2011. "Etika Bisnis Islami Dalam Praktek Bisnis Rasulullah.” Walisongo: Jurnal Penelitian Sosial Keagamaan 19 (1): 12756. https://doi.org/10.21580/ws.19.1.215.

Setiyawan. 2013. "Pengantar Bisnis." Journal of Chemical Information and Modeling 53 (9): 1-23.

Shafik, Siti Sa'adiah, and Nor Suhaily Abu Bakar. 2014. "Tauhid Membina Keutuhan Akidah Islam." Jurnal Islam Dan Masyarakat Kontemporari 2: 81-101.

Shihab, M. Quraish. 2011. Bisnis Sukses Dunia Akhirat. Ciputat: Lentera Hati.

Susidin, Susidin. 2010. "Pentingnya Etika Dalam Dunia Bisnis." Jurnal Ekonomi Dan Manajemen 5 (1): 42-47.

Widyatma, Zulfikar Yoga. 2014. "Konsep Kepemimpinan Menurut Al-Mawardi." Institute Studi Islam Darussalam 8 (1): 87-103. 